\title{
Akce je vhodná i pro Boha neznalé. Sondy do amatérského náboženského divadla na Moravě po roce 1990
}

\author{
The Event Is Suitable Even For Those Unacquainted With God. \\ Notes To Non-professional Religious Theatre in Moravia After 1990
}

Andrea Hanáčková

\begin{abstract}
Abstrakt
Autorka si klade za cíl popsat komunitní rozměr vybraných divadelních aktivit v regionu Moravy, které se soustřed'ují ve dvou vrcholech křestáanského roku, v období Vánoc a Velikonoc. $\checkmark$ prostředí střední a severní Moravy našla několik př́kladů amatérských divadel, která v období od roku 1990 připravila k jednomu uvedení nebo k pravidelnému opakování divadelní představení vánoční hry nebo pašijí. Jako východisko úvah a také jako výraznou autoetnografickou zkušenost označuje inscenaci Betlém režisérky Evy Tálské ve Studiu Dům, jejiž premiéra $\checkmark$ roce 1991 a její následné každoroční obnovené inscenování pod širým nebem položilo základ všech pozdějších pokusů profesionálních divadelníků o divadelní zpracování příběhu narození nebo ukřižování a zmrtvýchvstání Krista. Na amatérské divadlo má naopak vliv bud' silná tradice v daném prostoru, ještě častěji však osobní iniciativa jednotlivce, který nápadem a energií nadchne své sousedy a přátele. Další příklady vychází z farností (Rajhrad) a křestáanských komunit (Kroměříž, Olomouc). Leitmotivem studie je také zkoumání pojmu divadlo v souvislosti s popsanými aktivitami a jejich blízkost Bogatyrevovu pojetí sousedského divadla.
\end{abstract}

\section{Klíčová slova}

Amatérské divadlo; betlém; pašije; Živý betlém; komunitní potenciál divadla; Studio Dům; Eva Tálská; muzikál; oratorium; Petr Bogatyrev

\begin{abstract}
The aim of the paper is to describe the communal aspect of theatre activities in Moravia pertaining to the two peaks of Christian year - Christmas and Easter. A number of non-professional theatre groups in the region of central and northern Moravia that rehearsed and performed repeatedly or singularly Christmas and Passion plays in 1990 was found and described in the course of the research. One of the reference points, and an autoethnographic experience of the author herself, is The Bethlehem, a production by Eva Tálská, premiered in the Studio Dưm in 1991, which was repeatedly staged in the years to come under the clear sky. The Bethlehem became the paragon for later professional theatre revisitions of the story of Nativity, Passion and Resurrection of Christ. Non-professional theatre, on the contrary, drew from regional folk tradition or, more importantly, from personal fervour of individuals
\end{abstract}


who managed to ignite their friends and fellows for theatre work; another group of instances represents productions in parishes (e.g. Rajhrad) and Christian communities (Kroměříž, Olomouc). From the point of theatre theory, the paper addresses the semantic value of the term theatre in relation to the above-mentioned theatre activities and to Bogatyrev's concept of the Theatre of Neighbours.

\section{Keywords}

Non-professional Theatre; The Bethlehem; Passion play; The Live Bethlehem; community theatre; the Studio Dům; Eva Tálská; musical theatre; oratorio; Petr Bogatyrev

Studie je výstupem projektu IGA FF UP_ 2017_432102681 SGS-Osobnosti divadelní kritiky.

Ze spolkové kroniky, 15. 12. 2016: Letos jsme začali zkoušet Komedii o narozeni až po sv. Martinu, hodně věcí si pamatujeme od loňska. U souseda Bílého jsme objednali nové jesle. Slámu vezmeme od Valenty, zavinovačku půjčí Švédovi. Panu faráři bude třeba napsat úvodní řeč, je Rumun a české baroko nezná. ${ }^{1}$

Zájem o aktivity neprofesionálních divadelníků, kteří si nejčastěji sami pro sebe a vlastní komunitu připravují divadelní produkci na známé téma, začíná v českém kontextu už ve druhé polovině 19. století. V souboru divadelních her literárního historika Ferdinanda Menčíka nalezneme klasifikaci čtyř skupin těchto her s tradičními tématy: jedná se o hry vánoční a velikonoční a dále o hry se starozákonní a novozákonnî tematikou (MENČÍK 1894). Bogatyrev přebírá pojmenování „selské nebo sousedské hry“, zároveň ale upozorňuje, že „mnoho lidových her souvisí s městskými nefolklorními dramaty“ a že „mnohé lidové kusy vyšly ze školských her“ (BOGATYREV 1940: 22). Věnuje pozornost permanentnímu prolínání městského a vesnického vlivu na vývoj a podobu těchto her a dále se soustředuje také například na úlohu a postavení vzdělaných vesnických učitelů, častých organizátorů kulturního dění, kteří do lidových folklórních zvyků přidávali prvky přibližující sousedské hry „literární a divadelní tradici vyšších vrstev“. I následující příklady amatérského divadla, jež si jako téma volí náboženské téma, vychází téměř ve všech př́ípadech z městského prostředí vzdělanějších lidí, kteří tímto způsobem pomáhají navracet do moravské divadelní i folklórní tradice způsob oslavy narození nebo vzkříšení Ježíše Krista.

Za východisko uvažování o novodobých inscenacích amatérských divadel s pašijovým nebo nativním tématem považuji inscenaci Betlém brněnského Studia Dům, kterou soubor hrál každoročně v letech 1991 až 2000 a v posledních letech ji obnovil ve vícegene-

1 Kronika spolku Crhovská chasa. Zápis ze zkoušení vánoční Komedie o narození, ze dne 15. prosinec 2015. Nestránkováno.

2 Narození a smrt Ježíše Krista je samozřejmě taktéž v syžetu Nového zákona, mezi „novozákonní“ hry řadí Ferdinand Menčík především hry o světcích a hry novodobé (například sv. Dorota, sv. Barbora, sv. Jan Křtitel, ale také Jenoféfa, Bruncvík a další). 
račním obsazení. ${ }^{3}$ Po úvodním pojednání o této inscenaci jsou dále ve studii zmínkou nastíněny produkce profesionálního divadla, jež si sledované téma zvolily převážně až po roce 2000 jako součást repertoáru s akcentem na vánoční nebo velikonoční období v rámci konkrétní sezóny. V časové chronologii pokračuji ve studii popisem každoroční komunitní produkce Živého betlému v Rajhradě u Brna (2000-2016), nebot se jedná o názorný příklad divadla vzešlého z potřeb farníků a jejich rodin. Následovat budou ve výkladu dvě divadelně-hudební nastudování pašijového příběhu, která mají své kořeny v náboženské komunitě katolické a evangelických církví (Kroměříž, Olomouc). Cílem předložené studie je tedy postihnout komunitní rozměr divadelních aktivit, které se promítají do dvou vrcholů křestanského roku, kterými jsou období Vánoc a Velikonoc. Pouhý výčet ukazuje, že zásadní akcent studie bude položen na pojmenování mimoestetických funkcí tohoto typu divadla, přičemž zřejmě nevystačíme s těmi, jež ve svém spisu z roku 1940 vyznačil Petr Bogatyrev. Ten se ve druhé kapitole knihy Lidové divadlo v Čechách a na Moravě věnuje náboženské, magické, zábavní, ceremoniální, sociální, satirické a hospodářské funkci lidového a sousedského divadla (BOGATYREV 1940: 30-52). Předkládaná studie prozkoumá, zda jsou tyto mimoestetické funkce dnešního amatérského divadla na Moravě s náboženskou tematikou stále aktuální, př́ípadně zda se objevují nějaké další. Téma je pro mne do značné míry autoetnografickou zkušeností, v konkrétních částech studie se tedy objevuje i pohled přímé účastnice divadelních aktivit souvisejících s oslavou křestanských svátků liturgického kalendáře.

\section{Betlém, inscenace Studia Dům}

Zdálo by se, že po roce 1990 v nově nabyté svobodě ucítí divadelníci velký potenciál vánočního příběhu bud' v původní podobě pastýřských her, jak ji v českém kontextu představují Ferdinand Menčík, Julius Feifalik nebo Petr Bogatyrev, nebo v různých úpravách lidového sousedského divadla v novodobých adaptacích Jana Kopeckého. Než se takto tematizované divadelní produkce začaly objevovat, trvalo to řadu let. Profesionální divadelníci uváděli vánoční hry v adventním čase a pro školkové, školní i rodinné publikum až ve druhé polovině 90 . let. Spíše namátkou zmiňme v moravském kontextu nesmírně úspěšný Peškův Husovické Betlém (1997), který následně přebrala do repertoáru i řada českých amatérských divadel. Vlastimil Peška tuto hru později přepracoval na objednávku Městského divadla ve Zlíně a uvedl ji zde pod názvem Komedie o narození vizovického Ježišk a (2003). Brzy za sebou pak v následujícím desetiletí nastudovala různé verze vánočních her i další moravská divadla. Městské divadlo Brno uvedlo v roce 2009 inscenaci BETLEM, Pastorála aneb Hry vánoční v úpravě Václava Cejpka a režii Zbyňka Srby, inscenace se udržela na repertoáru do roku 2014. ${ }^{4}$ Jan Antonín Pitínský zpracoval

3 Od roku 2010 se v předvánočním čase schází dnes již dospělí bývalí členové Studia Dům, třicátníci a čtyřicátníci, a během tří dnů vždy znovu obnoví inscenaci pro jediné uvedení na schodech brněnského kostela sv. Michala. V rolích darovníčků, pastýřů i andělů už vystupují také jejich děti.

4 Realizační tým se však v tomto př́padě neinspiroval tradicí lidových vánočních her, ale nabídl publiku koláž ze starozákonních a novozákonních fragmentů, valašský písňový folklór, texty Franze Werfela, Milana Rúfuse a Ladislava Fukse. 
vánoční téma pro divadlo Husa na provázku (Převeliké klaněni právě narozenému Jezulátku aneb Betlém, 2006), v roce 2008 a 2009 uvedlo jeho úpravu vánočního příběhu Betlém aneb Komedie o narozeni Městské divadlo Zlín v režii Daniely Cádrové. Potenciál vánočního příběhu vycítila i malá soukromá divadélka kočující po kulturních střediscích, malých divadlech a školkách. ${ }^{5}$

Zásadní iniciační roli však na počátku všech těchto aktivit hrála režisérka Eva Tálská a její Betlém ve Studiu Dům, které začalo v Brně působit roku 1991.

Inscenace Betlém se stala východiskem jedné z původních hlavních linií Studia Dům a logicky navázala i na divadelní tradici, z níž vyrostla tvorba režisérky Evy Tálské a jejího učitele, dramaturga Bořivoje Srby. ${ }^{6}$ Součástí site specific projektů, jež vedly ke snaze získat vlastní divadelní dům, byla linie lidového divadla. Inspirace svátky, rituály a lidovými baladami vytvořila vstupní ideu tohoto souboru amatérů, výhradně mladých lidí a studentů vedených profesionály (FOJTÍKOVÁ, VRBOVÁ a OSLZLÝ 2012: 290). Betlém nastudovala Tálská jako divadelní podobu mechanických lidových betlémů, jichž se v Čechách do současnosti zachovalo jen několik.

Koncept inscenace postavila Tálská na principu živých obrazů, jež jsou rozpohybovány vždy v průběhu zpívaných koled a postupně se tak odvypráví nejpodstatnější část vánočního příběhu prostřednictvím krátkých dialogů, dějových písní a jednání postav. ${ }^{7}$ Inscenaci rámují výstupy pastýřů, kteří se dohadují, co přinesou Ježíškovi do Betléma. Nadřazený pojem „obraz“ nutně evokoval pečlivou práci všech scénografů, kteří rok za rokem začátkem listopadu inscenaci Betlém obnovovali a vždy ho v detailu nebo i podstatným způsobem proměňovali. ${ }^{8}$ Původní vedení Jany Prekové a Sylvy Hanákové postupně převzala Marie Jirásková, přičemž všechny vedle sebe vychovávaly další generaci scénografek a scénografư. ${ }^{9}$ Největší péče byla vždy věnována Svaté rodině, především stěžejní jevištní postavě Marii, jejíž obraz se každý rok znovu vytvářel. Jednoduchý bílý hábit zvýrazňoval dlouhý barevný závoj, jenž splýval z hlavy až na zem. Po řadu let byl červený, v některých letech však Tálská preferovala modrou barvu, k níž ji

5 Příkladem za desítky podobných agentur jmenujme dvoučlenné divadlo Koráb, které od roku 2010 nabízí vánoční titul Betlém založený především na pastýřské scéně a pro názornost doložený koledami za doprovodu instrumentální nahrávky s živým zpěvem a řadou interaktivních prvků. Podle sdělení principála souboru Radima Korába sehrají takto během prosince i dvacet repríz inscenace.

6 Právě dramaturg Bořivoj Srba a také Eva Tálská jako tehdejší asistentka režiséra Evžena Sokolovského stáli za slavnou brněnskou inscenací divadelních pašijí, Kopeckého úpravou lidových velikonočních her Komedie o umučeni a slavném vzkříšeni Pána a Spasitele našeho Ježišse Krista v roce 1965. Polistopadový vývoj od roku 1990 nabízel dramaturgickou svobodu znovu se k náboženskému tématu obrátit, na „velké“ pašije však Tálská se Srbou čekali dalších deset let, novodobá inscenace Komedie o umučení a slavném vzkřǐseni Pána a Spasitele našeho Ježišse Krista v brněnském divadle Husa na provázku měla premiéru 1. dubna 2000.

7 Tálská při zkouškách po hercích pravidelně požadovala, aby napodobovali figurky z betlémů, jak si je sami pamatují. Tyto pohybové etudy byly součástí i každoročních konkursů, při nichž se do Studia Dům hlásili stále noví zájemci ve věku 14-15 let.

8 V letech 1994-1997 jsem se přímo účastnila příprav a hraní Betlému jako členka Studia Dům, mé poznatky tedy vychází z autopsie. Za doplnění některých detailů děkuji Davidu Drozdovi a Pavlu Drábkovi.

9 Do scénografické dílny patřili pozdější studenti scénografie na JAMU, případně brněnské AVU, například Kateřina Hájková, Sylva Marková, Jan Dobeš, Dušan Šoltys nebo Tomáš Hrůza. 


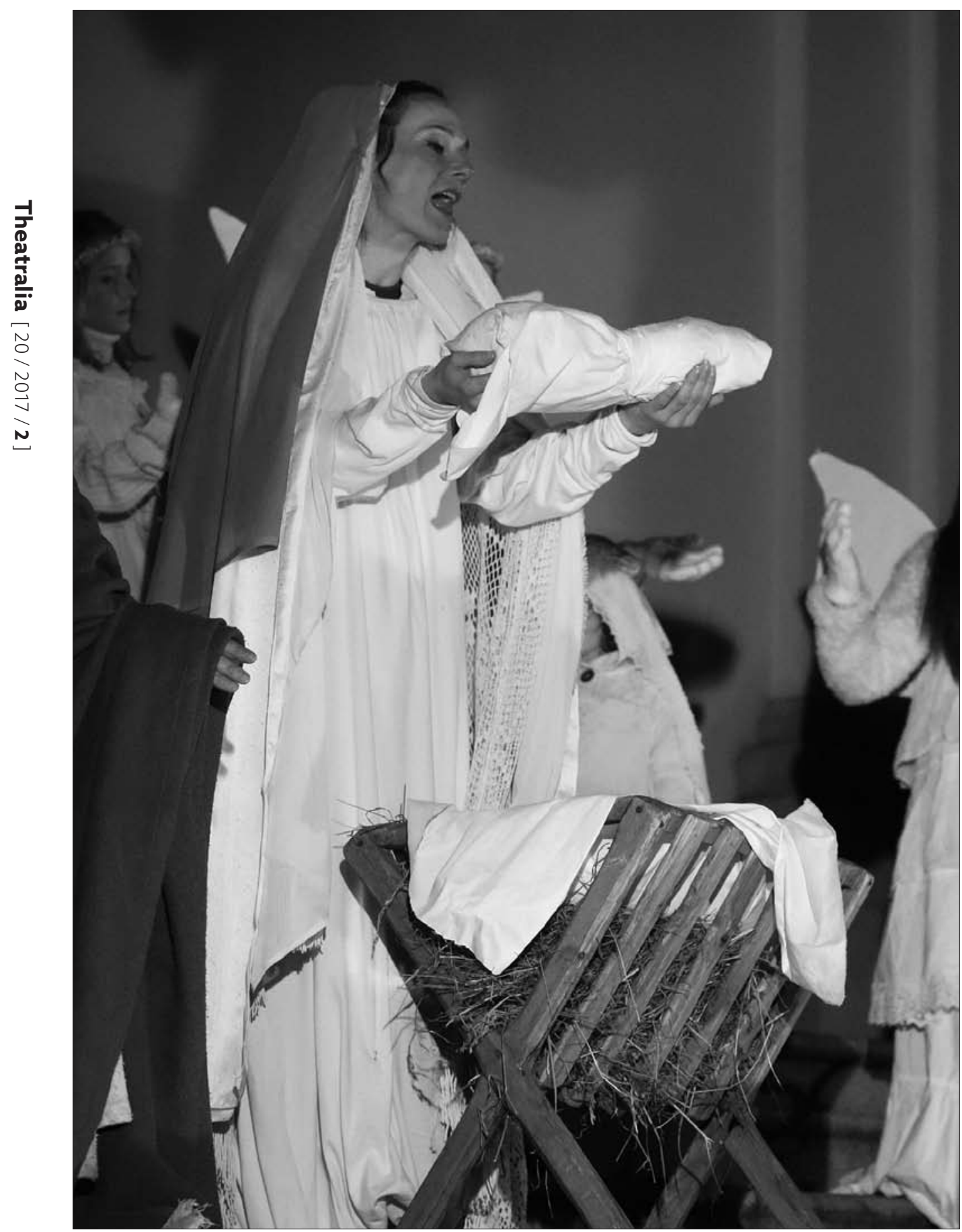

Obr. 1: Betlém, inscenace Studia Dům, režie Eva Tálská. Na snímku Jana Studničková jako Marie. Foto z obnoveného uvedení 19. 12. 2014, autor Attila Racek/ DENÍK. 


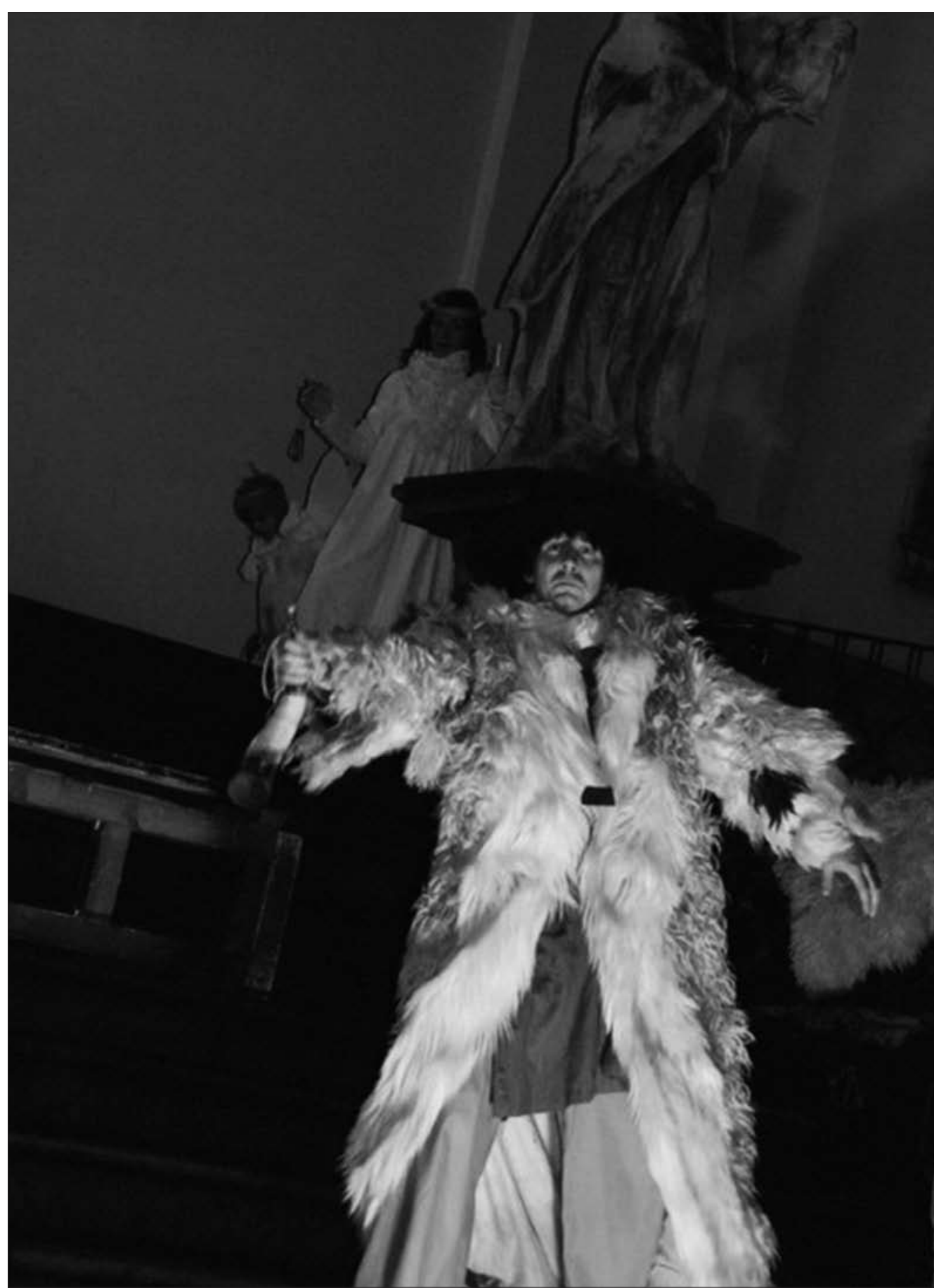

Obr. 2: Betlém, inscenace Studia Dům, režie Eva Tálská. Na snímku Tomáš Pavčík jako Pastýř. Foto z obnoveného uvedení 22. 12. 2010, archiv Studia Dům. 
inspirovaly gotické a raně renesanční Madony. ${ }^{10}$ Už ve verzi Betlému z roku 1992 se ve scénáři objevila koleda „Byla cesta, byla ušlapaná“ v instrumentaci Lenky Foltýnové. Obraz Marie, jež sama kráčí s dítětem v jedné a štoudví ve druhé ruce, tvořil zklidňující, tklivý obraz uprostřed veselí a radosti. Prostovlasý Josef měl jednoduchý hnědý hábit, Andělé byli ustrojeni v bílých košilích až na zem a jejich křídla vyžadovala na každou stranu téměř metrový prostor. Kostýmy muzikantů, selek a ostatních darovníčků pojaly scénografky v duchu jednoduchých citací lidových kostýmů, jež mohly navozovat folklorní asociace, častěji se však podřídily praktickému účelu a potřebám celkové barevnosti. Selky oblékaly bohatě řasené spodničky a na nich jednobarevné suknice s bílou zástěrou. Horní část oděvu tvořily vrstvy bílých košil a vestiček, schovaných však často pod vlňáky. Muzikanti mívali zdobené kabáty, dívky kratší, muži delší a jednobarevné sukně nebo vlněné kalhoty. Pastýřơm scénografové postupně z různých míst sehnali těžké kožichy, vesty z ovčích kůží a pořádné beranice.

Hudební složku představovala kapela složená ze členů Studia Dům, doplňovaná v nástrojovém obsazení podle aktuálních schopností jednotlivých herců. ${ }^{11} \mathrm{~V}$ kapele hrály basa, harmonika, klarinet, trubka, př́ičná flétna, dudy, housle, lesní roh, zvonec i třeba mandolína. Součástí hudební složky inscenace byly i zobcové flétny, na které hrály dívky z chóru koledníků a kolednic. Muzikanti mívali samostatné zkoušky a korepeticím se zpěváky byl vyhrazen samostatný čas zkoušení. Na kvalitu zpívaných a instrumentálních partů režisérka Tálská velmi dbala a těžce nesla situace, v nichž třeba kvůli velkému mrazu selhaly dřevěné hudební nástroje, nehrála flétna nebo se nepodařilo vyloudit tón ze zamrzlé horny. To všechno s sebou nesla skutečnost, že většina představení Betlému se odehrávala pod širým nebem, většinou v intenzivním sledu prosincových zájezdových představení v moravských městech, vesnicích okolo Brna, ale i v Praze nebo v Olomouci, na vánočních trzích ve Vídni a v Berlíně.

Představení vždy předcházel průvod, v jehož čele kráčel Anděl s trubkou. Za ním šla ve dvojici těhotná Marie, podpíraná Josefem, následoval veselý průvod darovníčků, pastýř̉ a muzikantů. Při některých představeních byla průvodu i hry účastna živá zvířata, osel a ovečka. V pečlivě vybraném a dopředu vždy obhlédnutém prostoru jsme po příchodu vytvořili výrazný živý obraz. Na některých místech zněl požadavek vytvořit shluk jevištních postav shromážděných kolem praktikáblu se Svatou rodinou, jindy jsme hráli na širším prostoru a požadováno bylo větší roztažení scény v horizontále. Vždy jsme však zachovávali maximální kompaktnost obrazu tak, aby připomínal právě lidový betlém postaviček, jejichž pozornost je upřena tu k ústřednímu vrcholovému výjevu Svaté rodiny, jindy k běžné práci (pastýř, peřinářka, selka). ${ }^{12}$ Velmi specifickým herním prostorem byly vždy kostelní schody, jež vytvářely představení přirozenou vertikalitu a umožňovaly hierarchické uspořádání živých obrazů v logice vánočního příběhu od prostých pastýřu na úpatí

10 Inspiraci jsme nacházeli např́klad na obrazech Roudnické madony Mistra Třeboňského, u Gentila da Fabriano, Giotta di Bondone nebo Stefana Lochnera.

11 Sekci hudební skladby vedl Miloš Štědroň a v jeho dílně se vyučili například Lenka Foltýnová, Jaroslav Panuš, Jan Srba, Pavel Drábek a řada dalších.

12 Výstižný popis inscenace podává i Kateřina Fojtíková v kapitole věnované pouze Betlému (FOJTÍKOVÁ 2012: 294-295). 


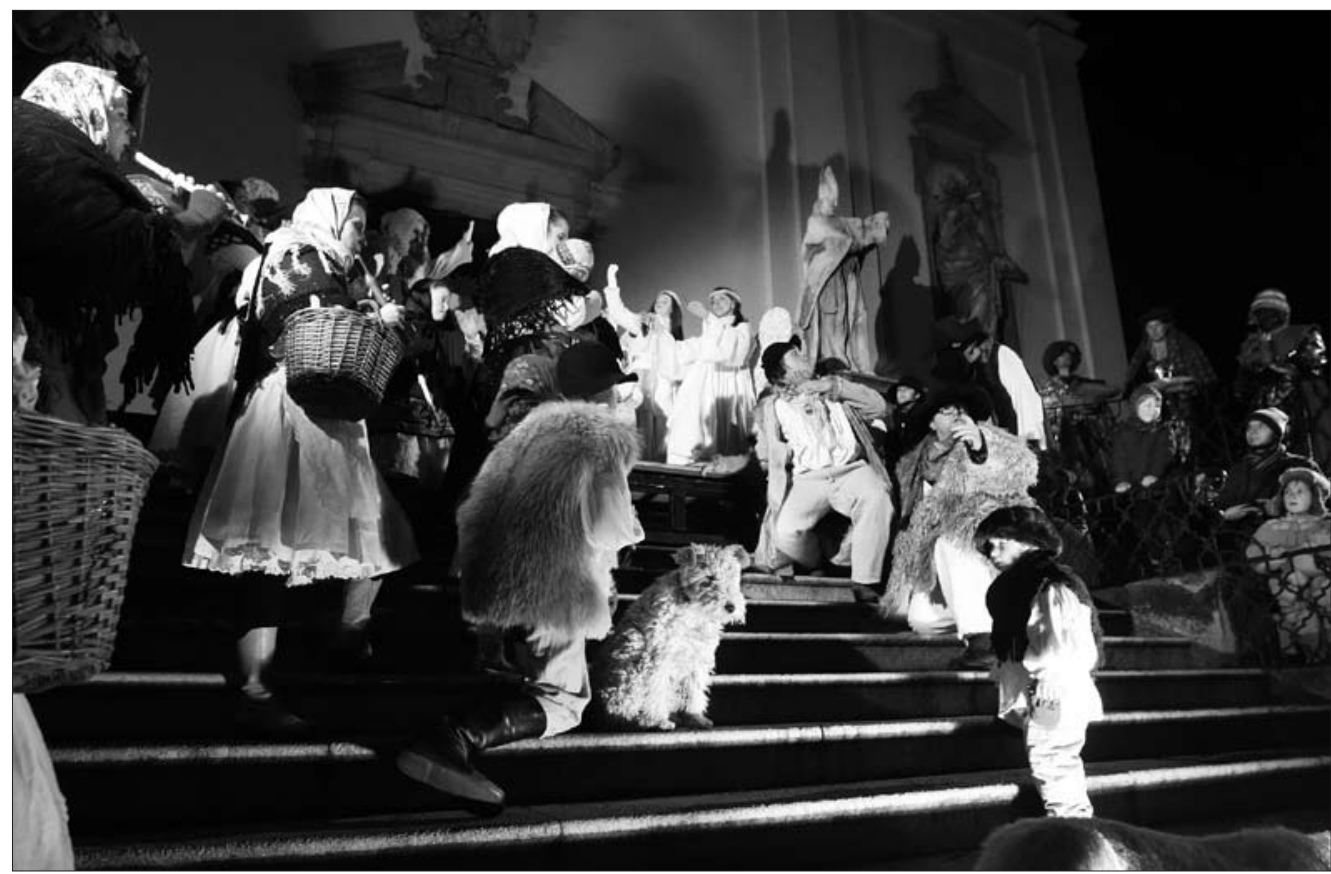

Obr. 3: Betlém, inscenace Studia Dům, režie Eva Tálská. Foto z obnoveného uvedení 19. 12. 2014 na schodech brněnského kostela sv. Michala, autor Attila Racek/ DENÍK.

schodů až k postavám andělů před kostelními dveřmi nahoře. Pro hraní, herecký pohyb i pohyb s hudebními nástroji byl takový prostor extrémně obtížný, výsledný scénický obraz však působil velmi efektně. Při podvečerním nebo pozdně odpoledním hraní jsme s sebou vozívali tři reflektory k čelnímu přisvícení a ke dvěma bočním přisvícením.

Tvorba inscenace probíhala - tak jako všechno ve Studiu Dům - ve společné práci, při níž se každý podílel hned na několika složkách tvůrčího procesu. Scénář vytvořila Eva Tálská na půdorysu starých vánočních her, jejichž podobu si nastudovala u Menčíka (1894), Feifalíka (1986), Sušila (1895) a Zíbrta (1910). Výjevy u jesliček rámovala pastýřská scéna, v níž se pastýři dohadují, kdo co Ježíškovi daruje. Svatá rodina potom nastoupila za zpěvu dialogické koledy „Josef, můj kochaný“. Po narození Ježíška se naplno rozehrály možnosti početného ansámblu shromážděného kolem Svaté rodiny. Scény krmení Ježíška, kolébání, pastýřská scéna i příchod Tří králů byly velkou příležitostí nejen pro konkrétní herce, kteří uplatnili svůj textový part, ale především pro všechny ostatní, aby v živé přítomnosti projevili mimicky a gesticky svůj podíl na oslavě narození nového krále. Tálská při zkoušení neustále zdůrazňovala, že je třeba myslet na celkový obraz. Každý jednotlivec měl svůj přesný úkol, určený gestický rozsah, specifický pohyb pro jednotlivé koledy, jenž průběžně ladil se spoluhráči a konzultoval s režisérkou. ${ }^{13}$ Přestože pro herce samotné znamenal tento typ hraní nesmírnou disciplínu,

13 Uvědomuji si, jak jsme si často během zkoušení i hraní upřesňovali, kdo se kam v které chvíli naklání, zvedá nebo posunuje ruku v gestu, otáčí hlavu nebo celý trup, případně se předklání nebo uklání na stranu. Zvlášt důležité to bylo v sekci muzikantů, kteří nebyli z tohoto mechanického opakujícího se pohybu nijak 
kázeň a občas i zjevné nepohodlí, sloužil v dané chvíli celku inscenace, jejíž úspěch byl založen právě na vzniklém dojmu hravosti, rozmanitosti a nerozjívené dynamice vycházející z tradiční podoby mechanických betlémů. Kateřina Fojtíková nachází ještě další charakteristiky této práce, hovoří o „nezatíženosti konvencí, chuti a času k experimentální práci, ochotě podřídit se přísným limitům celkové stylizace“ (FOJTíkOVÁ 2012: 294-295)..$^{14}$ Pro herectví byl typický rys, který Bogatyrev připisuje způsobu hraní v sousedských a selských hrách: „zesilování, přehánění pohybů odpozorovaných v denním životě, přeháněním gestikulace i mimiky“ (BOGATYREV 1940: 123). V silně stylizovaných gestech hrál např́klad Eduard Uličný starého pastýře Gryce, který „nemá nic“, jde se Ježíškovi s úctou alespoň poklonit a roztrhnou se mu přitom kalhoty. Velmi pomalým krokem, téměř v záklonu, v kožichu až na zem, s oporou o mohutnou hůl přecházel rozvážně přes celou šířku hracího prostoru jako skutečný kmet, komický ve svém patosu, opravdový v hluboké pokoře chudého pastýře.

Studio Dům bylo a stále je divadlem lidí ve věku 15-25 let, lidí, kteří přicházejí do prostoru Centra experimentálního divadla (CED Brno) a mají ve srovnání s ostatními amatérskými soubory nevídaně velkorysé podmínky na zkoušení inscenací. Přítomnost profesionálních učitelů a mentorů činí ze Studia skutečnou školu hereckou, autorskou, hudební, pohybovou a výtvarnou. Komunitní potenciál souboru tak efektivně umocňuje intenzitu práce a vede k vysoké kvalitě inscenací. Práce na Betlému znamenala každoroční pauzu ve zkoušení jiných inscenací, jimž byla věnována například letní soustředění, zájezdy během celého roku a pravidelné týdenní zkoušky. Zároveň vždy představovala návrat k inscenačnímu tvaru, který jsme důvěrně znali. Starší členové souboru zasvěcovali ty mladšś, inscenace se měnila $\mathrm{v}$ detailech, na některá místa jsme jezdili opakovaně a těšili se třeba na hojné občerstvení místních vděčných diváků. Inscenace Betlém tak v komunitě Studia Dům sehrávala podobnou roli jako v církevních nebo sousedských společenstvích, repetitivnost rituálu potvrzovala kořeny divadla i potenciál souboru k efektivní souhře a radosti z hraní.

\section{Rajhradský Živý Betlém}

Zcela jinak chápe „svo̊j Betlém“ komunita lidí z Rajhradu u Brna, jež se od roku 2000 každoročně schází na Boží hod odpoledne, aby představila lidem živý výjev Svaté rodiny. „Nikdy by mě nenapadlo to prezentovat jako ,divadlo““, ohrazuje se Magda Mlejnková ${ }^{15}$, místní varhanice, duše celé akce. V její představě je pojem divadlo spojen s měštanským prostorem portálového jeviště, jemuž dominuje silně stylizovaná komedie s výraznými

vyňati, ale museli přitom zároveň hrát na hudební nástroje, často obtížně instrumentované party jednotlivých koled.

14 Soupis recenzí na jednotlivé inscenace Studia Dům (včetně Betlému) v letech 1991-2000 viz (FOJTíKOVÁ 2002: 369-374).

15 Mgr. Magda Mlejnková je vystudovaná učitelka náboženství, varhanice, sbormistryně, v současné době uvolněná místostarostka města Rajhrad. Většina informací pochází z osobního rozhovoru s Magdou Mlejnkovou, který jsme vedly 3. 11. 2016 v Rajhradě. Záznam v archivu autorky studie. 
maskami, příčesky a parukami. Rajhradský Živý Betlém je podle Mlejnkové zcela vzdálen této bulvární podobě divadla. Při charakteristice tradiční vánoční produkce se odvolává na vnitřní pocit účastníků, pokoru a náboženský přesah setkání umocněný aktivní účastí katolických duchovních. Jak postupně vyplyne, akce má i výrazný komunitní potenciál posilování ducha konkrétní diecéze a pocty pro konkrétní členy společenství. Souhrn všech těchto kvalit podle Mlejnkové odporuje tradiční podobě divadla. ${ }^{16}$

Pouhá deskripce rajhradského Živého Betlému však vzápětí ukáže, že produkce samozřjejmě má všechny atributy divadelní podívané. Terminologický rozpor ukazuje na rozdílné recepční akcenty v chápání divadelní tradice i v současném pojetí performančního umění.

Komunitní rozměr rajhradského betlému začíná již přípravnou fází. Na vymezeném, mírně vyvýšeném prostoru uprostřed rozsáhlého nádvoří místního benediktinského kláštera vystaví sehraná skupina dobrovolníků o víkendu před Božím hodem základní scénu, přístřešek pro Svatou rodinu. Vpravo od ústředního výjevu se nachází prostor pro pěvecký sbor a muzikanty, vlevo stojí ohrada pro zvírata. Prostor pro diváky vymezuje nápis Sláva Bohu na výsostech, upevněný na dřevěných kůlech před hracím prostorem. Obrácené barely na vodu slouží jako vyvýšené místo pro anděly. ${ }^{17}$ Samotné představení začíná čtením u mikrofonů, dva moderátoři odvypráví úvodní scénu a za zpěvu koled přichází k jeslím Svatá rodina. Následně stejnou cestu urazí koledníci, před jeslemi pozvednou do výše svůj dar, ukáží ho divákům, uloží ho k jeslím, ukloní se a zařadí se do celkového obrazu. ${ }^{18}$ Takto chodí koledníci jeden za druhým, čímž postupně vytváří obraz Živého Betléma. Spolu se sborem zpívají i diváci, kteří dostávají texty koled vytištěné na papíře. Celé prostranství je zaplaveno světlem z veřejného osvětlení. Podává se horký punč, děti si mohou pohrát se zvířaty. Představení končí společným zpíváním, lidé pak zůstávají na místě a povídají si. V posledních letech se Betlémů účastní zhruba třicetihlavý sbor zpěváků, 70 koledníků a 10 pomocníků v technickém zázemí celé akce. Diváků se schází 500 až 800. Rozsahem jde zřejmě o největší Živý Betlém na Moravě.

Volnou inspiraci k jeho výtvarné podobě našla Mlejnková před lety v papírovém betlému ilustrátorky Marie Kvěchové, jež v tradičním výjevu zobrazila krojované selky, řemeslníky, muzikanty v krojích upomínající na dobu předminulého století. Svatá rodina je na něm vyobrazena s atributy oděvů z blízkého Východu (HÁNL a HÁNLOVÁ 2011). Podle těchto obrázků do Živého Betlému postupně přibývali koledníci tak, jak se další a další rajhradští farníci chtěli božíhodové slavnosti účastnit. Část kostýmů si účinkující pravidelně půjčují z kláštera místní kongregace ženského řádu sester Těšitelek. Andělé hrají ve vypůjčených svatebních šatech, v průvodu chodí ženy i muži v tradičních mo-

16 „Každý koledník tam jde sám za sebe, jejich vnitřní pocit je především pokora, s níž přicházejí k jesličkám. Jsou nositeli daného řemesla nebo povolání, zástupci některého stavu, a když se klaní narozenému králi, jde o výraz nejhlubší úcty a většinou i víry v Krista. To s divadlem nemá co dělat.“ Osobní rozhovor s Magdou Mlejnkovou. Rajhrad, 3. 11. 2016. Záznam v archivu autorky studie.

17 „Zvučit nám to chodí Pepík, halogenky mají benediktíni“, komentuje Magda Mlejnková zvukovou a světelnou stránku představení. Tamtéž.

18 „Pastýři při zpěvu koledy berou dary a s ponocným odcházejí k Betlému, pokloní se, odevzdají dary a zůstanou u Betléma. “ Pracovní scénář Živý Betlém, nedatováno, nestránkováno, podle sdělení M. Mlejnkové jde o verzi před rokem 2008. 


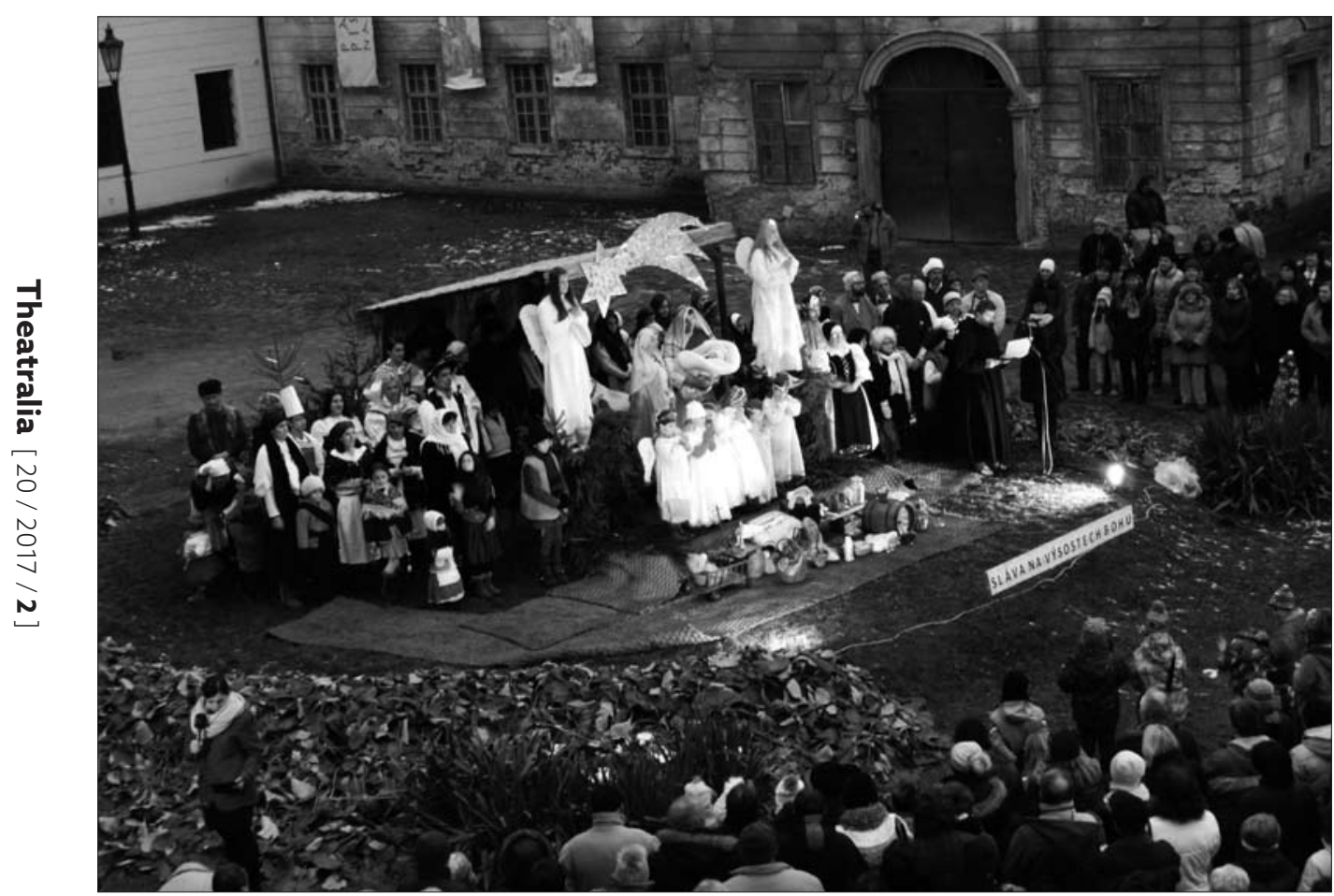

Obr. 4: Živý Betlém 2016, Rajhrad u Brna, celkový pohled na nádvoří benediktýnského kláštera. Foto Ladislav Pohl.

ravských krojích, z nichž některé se v rodinách dědily z generace na generaci, jiné si nechali místní po roce 1989 znovu ušít nebo obnovit. ${ }^{19}$ Zároveň se postupně precizují jednotlivé dary, ke každé ošatce, soudku medu, demižónu vína, dřevěnému koníkovi nebo hromádce dřevěných bílých vajec se váže nějaký drobný příběh, jde o předměty denní potřeby z konkrétních domácností. ${ }^{20}$ Scénografii přitom nemá nikdo v komunitě jako samostatný úkol, vše vzniká intuitivně, domluvou a podle vnitřního pocitu koledníků, přičemž původní inspirační zdroj, Betlém Marie Fischerové Kvěchové, slouží jako volná inspirace.

Průvodní slovo původně přebírala scenáristka Mlejnková z Evangelia sv. Lukáše. Předčítač textu je v pracovním scénáři označen skutečně jako Lektor ${ }^{21}$ a objevují se zde

19 Tuto situaci výstižně popisuje Jiřina Langhammerová: „Čas od času při místní slavnosti zazáří původní ustrojení se vším, co k takovému tradičnímu úboru patří - množství navrstvených sukní dává kroji košatou siluetu, uplatní se dovednost vázání, řasení a tvarování šatu, které spolu s patřičným chováním lidí v tomto ustrojení vytváří specifický kulturní celek." (LANGHAMMEROVÁ 2004: 225-226)

20 Mlejnková mi vyprávěla, jak postupně vznikala dřevěná kopa bílých vajec, již si konkrétní kolednice sama vyrobila; pověstný je také příběh betlémské hvězdy, dominující celému přístřešku Svaté rodiny. Vznikla narychlo v průběhu několika nočních hodin těsně před prvním Živým betlémem s ideou, že je to ,jen taková improvizace“, kterou pro příští ročník konkrétní rodina předělá. S touto hvězdou hraje komunita dodnes, k „předělání“ nikdy nedošlo.

21 V katolické liturgii je pojmem lektor označena osoba pověřená úkolem předčítat čtení z Písma svatého. 
přímé citace kapitol a veršů evangelia („,2,9 Náhle při nich stál anděl Páně a sláva Páně se rozzáŕila kolem nich.“222. V roce 2008 pocítila komunita potřebu změny. Mlejnková průvodní slovo aktualizovala a charakter úvodu do Živého Betlému se výrazně proměnil. Průvodci jsou dva a ve scénáři nesou označení Vypravěč. Narativ vyprávění o narození Ježǐše průběžně narušují publicistické vsuvky, jež celý příběh aktualizují a přenáší ho do reality českých vánočních domácností:

\footnotetext{
Druhý vypravěč: Představ si předvánoční shon. Doma se připravuje vánoční cukroví, peče se vánočka, žena si pochvaluje těsto, jak se jí zrovna dneska povedlo, ruce má od mouky a do toho...

První Vypravěč: Zvonek!

Druhý Vypravěč: Ano. Žena si rychle utře umazané ruce, no jo, vždyt už jdu. To je spěchu! A cestou ke dveřím přemítá, kdo to asi může být. ${ }^{23}$
}

Nastolená situace se rozvíjí vnitřním monologem ženy, následuje dialog s dvojicí neznámých cizinců, z nichž se v metafoře stávají právě unavení Josef s Marií. Podle Mlejnkové má tato aktualizovaná verze velký úspěch a oslovuje lidi prostřednictvím jazyka, jemuž dobře rozumějí. ${ }^{24}$ Po moderátorských promluvách následuje obřad darování, herci v jednotlivých rolích němě vykonávají svůj úkol a řadí se do výtvarného obrazu. Mlejnková tvrdí, že kdyby od koledníků chtěla, aby ve své roli deklamovali text, většina by z předvádění betlému odešla. ${ }^{25}$

Je tedy zjevné, že jde o výsostně divadelní tvar. Scénografická, produkční, kostýmní i herecká složka jsou založeny na postupně budované tradici, ústní domluvě, dobrovolnictví i jisté společenské prestiži, jež každoročním představením rajhradského Betlému v místních poměrech narůstá. Proč se tedy vlastně „betlémáři“, jak se navzájem titulují, tolik brání tomu, že „dělají divadlo“? Jádrem tohoto pocitu je kalendrický rituál, komunitní podstata celé akce. Bogatyrev hovoří v této souvislosti o divadelní produkci jako o „prodloužení bohoslužby v kostele“. Svůj postřeh spojuje například se zvoněním kostelního zvonu nebo modlitbou v rámci divadelního představení (BOGATYREV 1940: 37). Touha každoročně se aktivně účastnit Živého Betlému vychází ze skutečnosti, že většina účinkujících jsou farníci rajhradské farnosti, přestože naprosto nejde o podmínku účasti. Mlejnková jako varhanice a sbormistryně dvou dětských sborů získává nové herce „přes děti“, působí na dospělé skrze kontakt a komunikaci s jejich dětmi. Svatou rodinu představuje vždy konkrétní rodina, která má aktuálně čerstvě narozené dítko. Za dlouhá léta

22 Pracovní scénář Živý Betlém, nedatováno, nestránkováno. V majetku Magdy Mlejnkové.

23 Pracovní scénář Živý Betlém Rajhrad 2008, nestránkováno.

24 Prvoplánové doslovné poselství vánočního příběhu je zjevně i dobře mediálně čitelné. Např́klad po podzimních událostech roku 2015 měl tento zpo̊sob moderování biblického příběhu velmi silné konotace na společenskou atmosféru v zemi související s uprchlickou vlnou a šířením paniky v české společnosti, uprchlíky v podstatě zcela nedotčené. „V Rajhradě se ptali: Vzali byste k sobě Josefa s Mariî?“, táže se titulek jednoho z článků (ČERNÝ 2015, dále HOLAS 2012; ZDENĚK 2015; HORÁKOVÁ 2011), jenž o Živém Betlému informuje a jednoznačně odkazuje ke skutečnosti, že Svatá rodina putovala zemí bez prostředků, žena ve vysokém stadiu těhotenství a přicházela ke dveřím hostitelů s pouhou prosbou o př́střeší a elementární pomoc.

Osobní rozhovor s Magdou Mlejnkovou. Rajhrad, 3. 11. 2016. Záznam v archivu autorky studie. 


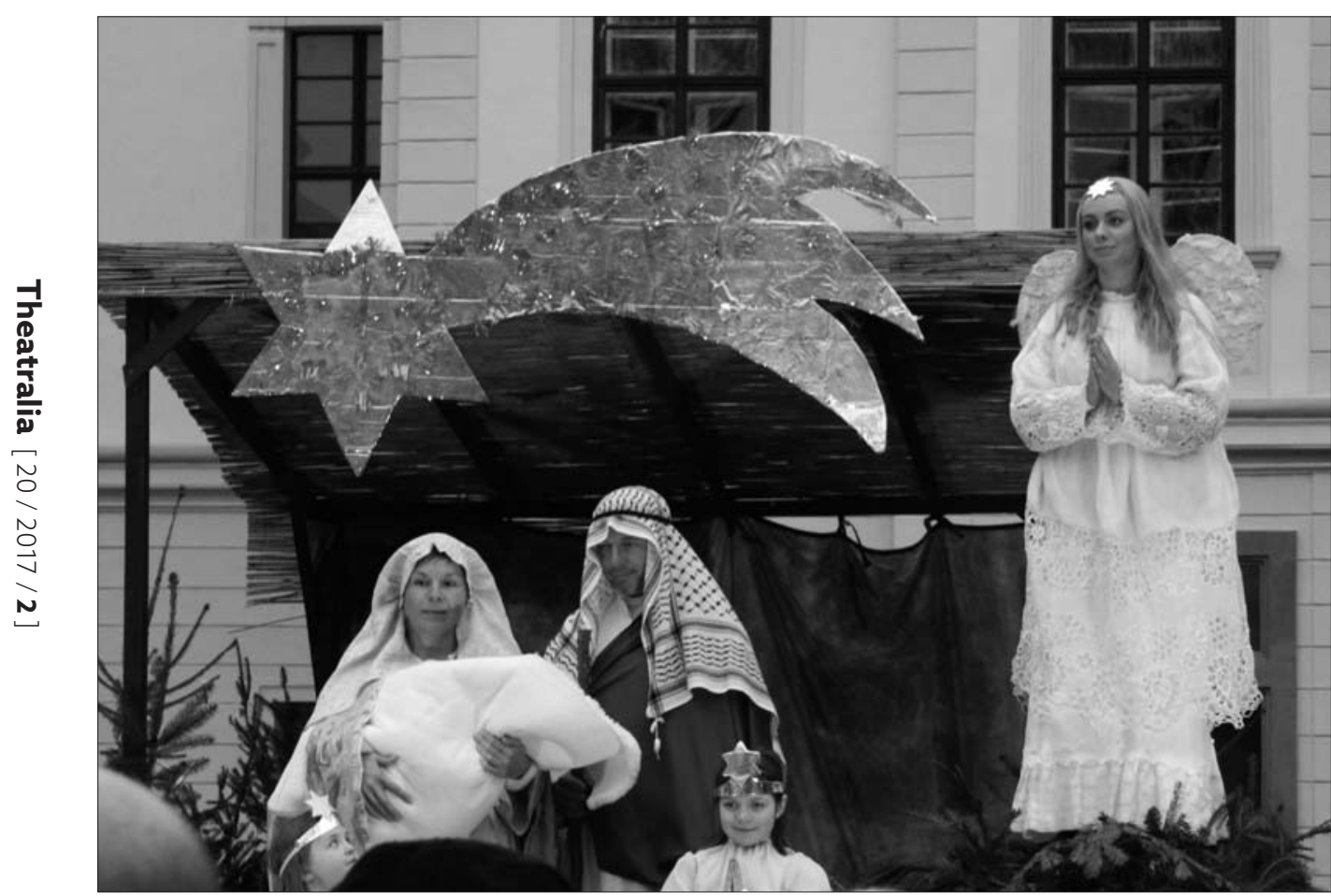

Obr. 5: Živý Betlém 2016, Rajhrad u Brna, svatá rodina, manželé Jarmila a Tomáš Cabákovi se svojí dcerou Anežkou. V popředí v rolích andělů Adélka a Barunka, starší dcery Cabákových. Foto Ladislav Pohl.

nejsou výjimkou rodiny, které do jesliček jako Ježǐška postupně položily všechny své děti, chlapce i dívky. Skutečnost, že představitelé Josefa a Marie tvoří reálný pár a jejich skutečné dítě „hraje“ právě narozeného Ježĩška, dodává celé slavnosti výrazně performativní ráz reálného obřadu přivítání právě vzešlé naděje v novém životě. ${ }^{6}{ }^{6}$ Vybrané rodiny si považují za čest stát se pro konkrétní rok Josefem a Marií a klanění před Svatou rodinou tak představuje, kromě zobrazení Narození Páně a adoraci jesliček, vzdání holdu konkrétním lidem a přání všeho dobrého jejich dítěti. Jak děti rostou, dostávají postupně další role darovníčků nebo andělů a tradice božíhodové slavnosti Živého Betléma se prohlubuje. „Když jsem tady nastupoval, byl mým prvním Ježǐškem Vojtěch Kocman“, vzpomíná páter Vojtěch, který betlémy dlouhá léta pomáhal organizovat a býval také jejich moderátorem. „Hodně mi ale v paměti utkvělo to, že když jsme Živý Betlém pořádali podesáté, prošlo všech devět předchozích Ježíšků poklonit se tomu desátému. “27

Propojení obce s živou reálnou rodinou a jejich dítětem, pokračování náboženského

26 „Z patnácti dosavadních Ježǐšků jich nejvíc dodala rodina Vlasákových, která měla ve třech letech hned čtyři. Nejprve se jím stala před jedenácti lety Valerie, před osmi roky Adam a v roce 2010 dvojčata Viktorie a Alžběta." (TROJAN 2015) Magda Mlejnková informaci upřesnila tak, že se dvojčata v jesličkách v polovině Betlému vystřídala, aby to „v budoucnu žádné z dívek nebylo líto“. 
rituálu v obřadném průvodu i silné komunitní cítění jednotlivých nositelů rolí s diváky, jež jsou členy stejného společenství, to vše ukazuje na množství mimoestetických funkcí, které takové pojetí Živého Betlému plní. Je zjevné, že funkce religiózní a obřadní přesahují zážitek estetické podívané, tím spíše, že se všichni diváci podílejí na společném zpěvu známých koled. Aktualizace průvodního slova plní dále funkci osvětovou, zásadní je také mezigenerační přesah setkání a pobídka k udržení lidových tradic např́klad $\mathrm{v}$ podobě lidových krojů.

Rajhradský Živý Betlém tvoří svým rozsahem a dlouhou tradicí vrchol amatérských divadelních produkcí vážících se $\mathrm{k}$ vánočnímu období. Je třeba říci, že v moravském regionu nacházíme po roce 2000 desítky podobných výjevů živého betlému. Často jsou doplňkem vánočních trhů, slouží jako rámcový př́iběh různých školních divadelně-hudebních produkcí. $\mathrm{K}$ dalšímu výzkumu amatérských divadelních aktivit se nabízí taková představení, $\mathrm{v}$ nichž potřeba vánočního setkání vyvěrá z komunitní podstaty společné tvorby (Živý Betlém ve Václavově na Zábřežsku, Komedie o narozeni v Crhově na Štítecku, Živý Betlém v jihomoravské Strážnici).

\section{Olomoucké a kroměřižské pašije}

Druhá část studie obrací pozornost k nejvýznamnějším svátkům křesłanského roku, k pašijovému týdnu, připomínce umučení, smrti a vzkřĩšení Ježíše Krista. Divadelní pašije mají bohatší novodobou historii než vánoční hry a často se jich ujímají drobná křestanská společenství, soustředěná v jediné farnosti. Takto vznikly např́klad Pašije v Hulíně, inscenace $\mathrm{s}$ profesionálními zpěváky a sborem sestaveným $\mathrm{z}$ hudebních laiků, která se v nepravidelných reprízách objevuje v tamní farnosti od roku 2000. Zároveň však vyžadují pašije obvykle velkorysejší výpravu, velké množství účinkujících, dobrou koordinaci jednotlivých tvưrčích složek a náročnou produkci. Nejčastěji mají podobu zpívanou, jako například Pašije Zdeňka Angelika Mičky, které provedl Komorní sbor Uherský Brod v roce 2012 jako čistě koncertní provedení, ale mohou mít i podobu kostýmovaného oratoria, jako například produkce schuoly římskokatolické farnosti v Uherském Hradišti, kde byly Pašije provedeny o Velikonocích roku $2015 .{ }^{28} \mathrm{Z}$ dostupných zdrojů vybírám jako př́klad dvoje novodobé pašije, jejichž nosným uměleckým vyjádřením je především zhudebněný pašijový příběh a píseň jako ústřední tvưrce dramatické situace.

Myšlenkou připravit pro Olomouc Pašije se Jarmila Bekováa ${ }^{29}$ zabývala čtrnáct let. Postupně psala slova a melodie písní, které vyprávěly pašijový př́iběh z pohledu lidí, kteří Ježǐše obklopovali a žili v dané době. Východiskem byly samožrejmě biblické texty, především Janovo evangelium, písně jsou však výsostně autorské. Beková vypráví např́íklad

28 Jednou z typických produkcí tohoto druhu pašijí jsou folkově-rockové Živé pašije, projekt, který po tř̌i léta (2010-2012) plnil kostely především v domovské Litomyšli a v dalších českých městech. Regionem nespadá tento projekt do zájmové oblasti studie, jeho vznik, průběh, účinkující a jejich entuziasmus však plně vystihují myšlenku komunitního divadla s náboženskou tematikou. Více Živé pašije. Dostupné online na http://zivepasije.webnode.cz/o-projektu/.

29 Mgr. Jarmila Beková, Ph.D. je absolventkou Univerzity Palackého v Olomouci, českou filoložkou a francouzštinářkou. Na stejné univerzitě působí v současné době na Katedře romanistiky. 
o pocitech matky, jíž umírá na kř́iži syn, ${ }^{30} \mathrm{v}$ písni Prázdnota reflektuje pocity učedníků ve chvíli, kdy jim odešel učitel. ${ }^{31}$

V době, kdy počet písní dosáhl počtu třináct a vytvořil logický celek, začala Beková zvažovat, jak dílo provést, respektive, ,jak písně propojit““. ${ }^{32}$ Tradiční metodou, již využívají místní spolky například pro příběh narození Ježíška, je proložit písně biblickými texty. ${ }^{33}$ Beková však uvádí, že její ambicí bylo pašijový příběh aktualizovat. Podobně jako jsme viděli v případu rajhradského Živého Betlému, i v tomto případě se autorka projektu vymezuje vůči označení své produkce slovem „divadlo“. Duchovnímu světu evangelické církve je mnohem bližší představa sboru, sólového zpěvu, hudební produkce a čtení. Texty propojující jednotlivé části tedy nakonec taktéž napsala sama a zvolila formu poetických vypravěčských textů. Výsledný tvar nazývá oratoriem, jakkoli terminologie není ustálená ani mezi účinkujícími, ani v propagačních materiálech.

Beková se pokoušela nabídnout myšlenku zpívaného pašijového příběhu ekumenickému společenství olomouckých evangelických církví několik let, ale uspěla až v prosinci roku 2015, kdy v nadšení z právě skončeného vánočního koncertu vyzvala skupinu hudebníků ke spolupráci na projektu Pašije 2016. ${ }^{34}$ Sólisty vybrala Beková podle hlasových dispozic nejlepších zpěváků, jež znala, jednotlivé postavy představovaly například Ježíše, Piláta, Lotra na kř́í̌i, Marii. V tomto případě se nejednalo o vytváření rolí, postavy jsou statické, drží v ruce složku s notami, případně užívají jednoduchá pěvecká gesta, jen drobným kostýmním náznakem jsou odlišeny od ostatních účinkujících (například trnová koruna pro Ježíše, červená kravata nebo šátek). ${ }^{35}$

Východiskem celého procesu zkoušení novodobých olomouckých pašijí je hluboká praktikovaná víra a přátelství s lidmi z olomouckých evangelických církví. Komunitní rozměr duchovního života byl klíčovým předpokladem pro vznik ekumenické hudebně-scénické produkce. Výraznou podporu myšlence dodali samotní kazatelé, kteří ve svých sborech šířili povědomí o připravovaných olomouckých pašijích a někteří v nich pak sami účinkovali. Kazatel baptistů hrál na klávesy, kazatel Církve bratrské obstaral party pro příčnou flétnu, na trubku hrál kazatel Církve Nové naděje a ve sboru zpíval kazatel Křestanských sborů. Inscenace má čtyři základní složky, které se

30 Verše jednotlivých písní mají různorodou kvalitu: „Všichni se jenom dívají, jak můj syn trpí na kř́̌̌ii, / už ani slzy nemám, jen bolest cítím. / Kus mého srdce umírá, jsem jako třtina zlomená, / tvá hvězda padá, je konec žití." Ukázka z písně Matka pod kř̌žem, citováno podle internetové stránky Pašije 2016. Dostupné online na http://pasije2016.cz/pisne/.

31 Velmi komplexní informace doplněné o množství detailů o jednotlivých účinkujících a kompletní soubor písňových textů, ukázek a množství fotografií jsou dostupné na webových stránkách projektu Pašije 2016. Dostupné online na http://pasije2016.cz/projekt/.

32 Osobní rozhovor s Jarmilou Bekovou, 26. 8. 2016. Záznam uložen v archivu autorky.

33 Takto je např́íklad vystavěn Živý Betlém ve Václavově na Zábřě̌sku, kde se pásmo z koled a biblických čtení z evangelií stává vítanou př́ležitostí k sousedskému setkání těsně před Štědrým dnem.

34 Muzikanti, často profesionálové nebo poloprofesionálové, byli pro inscenování Pašiji klíčoví. Jakkoli je Beková zdatná hudebnice a zpěvačka, netroufla si na propracované aranže pro větši množství nástrojủ. Hudebníci tedy řešili aranže formou jamování, společně nacházeli způsoby, jak písně z jednoduché melodické linky propracovat pro třináctičlennou kapelu.

35 Pašije 2016. DVD, pracovní záznam představení. 


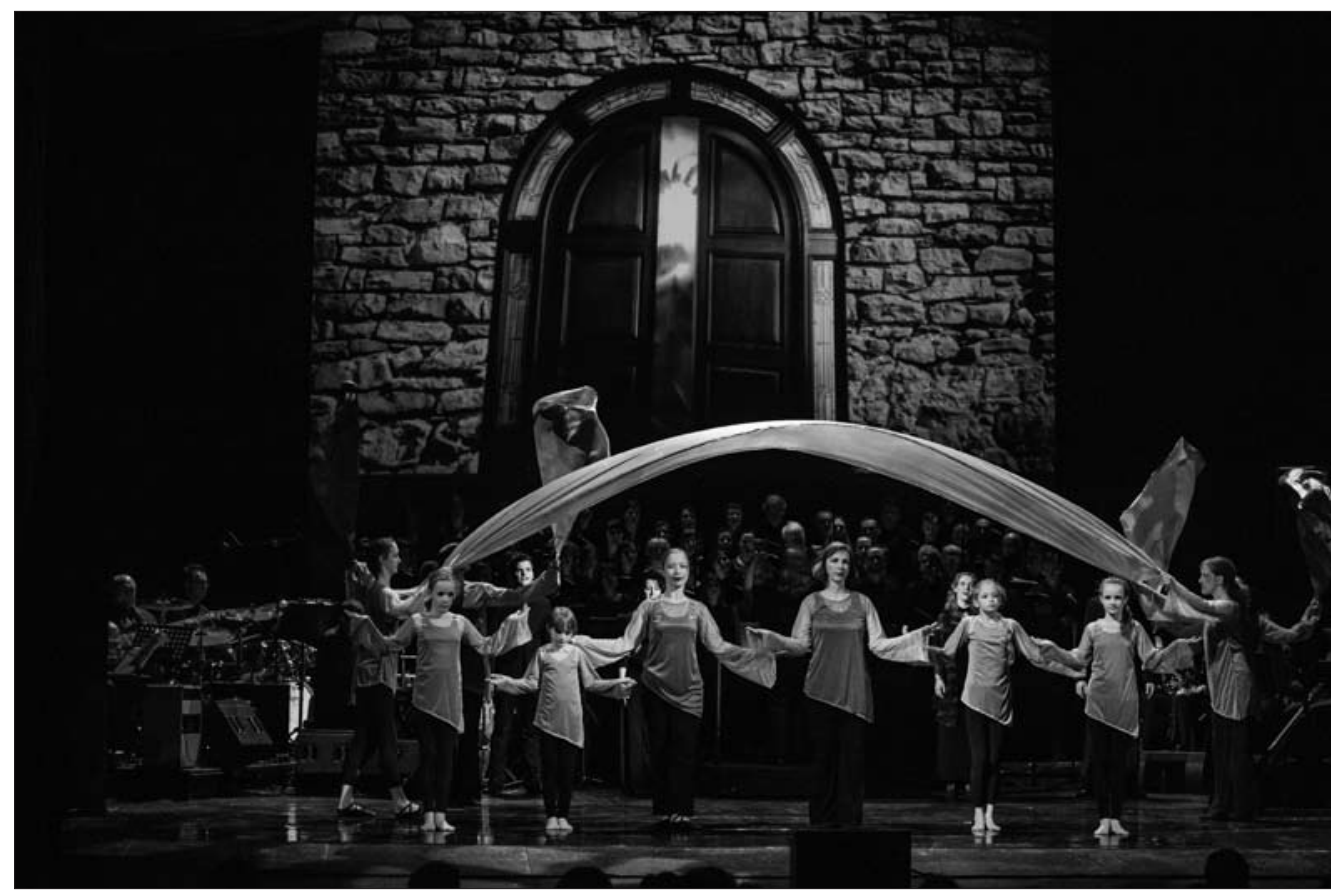

Obr. 6: Pašije 2016 Olomouc, představení 17. 4. 2016 v Moravském divadle Olomouc, scéna Vjezd do Jeruzaléma. Foto Daniel Schulz.

tvůrci snažili co nejkompaktněji propojit. Nejintenzivněji zkoušeli hudebníci a sboristé, jejich party střídali sóloví zpěváci, v pohybových choreografiích se představil sbor, poslední součástí inscenace byly projekce. Inscenace nemá svého scénografa ani výtvarníka, tvorba i následná syntéza složek tedy probíhala zcela intuitivně. V pohybu šlo spíše o jednoduché choreografie a mizanscény: v situaci modlitby v Getsemanské zahradě vytváří tanečníci spící učedníky, ve scéně u Piláta představují nespokojený dav. Tanečníci využívají univerzálnost černého trikotu doplněného volným hábitem asymetrického střihu s dlouhými zvonovými rukávy. V takto unifikovaném kostýmu ztvárňují pohybové kreace, jimiž v lyrizujících choreografiích dokreslují atmosféru písní. Podobně ilustrativně a melodramaticky se pracuje s projekcemi, které Beková nazývá „náladové“. Při scénickém ztvárnění modlitby v Getsemanské zahradě se ve filmové smyčce komíhají uschlé větve stromu ve větru, při zpěvu neštastné matky pod křížem padají v projekci vločky z nebe, při vjezdu do Jeruzaléma se na obrovském plátně otvírají masivní vrata v kamenné zdi a podobně.

Cílem Jarmily Bekové rozhodně nebylo vytvořit divadelní pašije. Jejich tradici nezná, po textech, které pašijovou tradici dramaticky zpracovávají, nepátrala. ${ }^{36}$ Stěžejní kvalitu celého divadelního projektu tak opět tvoří komunitní rozměr procesu tvorby a podpora př́íslušné širší obce.

36 „Takové tradice jsem sama v evangelikální tradici nezažila. Nejdůležitější bylo naše vyjádření, naše potřeba to spolu prožít." Osobní rozhovor s Jarmilou Bekovou, 26. 8. 2016. Záznam uložen v archivu autorky. 
V Olomouci existuje dlouhá tradice spolupráce evangelikálních církví. ${ }^{37}$ Bekové se podařilo nadchnout pro myšlenku pašijového oratoria nejen olomoucké věřící, na zhruba 7 víkendových zkoušek přijeli i lidé z Vyškova, Zábřehu, Litovle, Prostějova a okolních vesnic. Zpráva se šírila, zpěváků a tanečníků stále přibývalo. I díky tomu bylo velmi rychle vyprodáno Moravské divadlo a Pašije nepotřebovaly žádnou propagaci. Díky plakátům na veřejných plochách pouze dali organizátoři na vědomí, že se podobná akce koná. Už měsíc dopředu ale věděli, že je na Velikonoční pondělí uvidí zhruba 800 lidí. ${ }^{38}$ Přestože měli jen jedinou zkoušku v prostoru a svícení ve velkém měštanském divadle víceméně improvizovali, sklidila inscenace obrovský úspěch v komunitě rodin a příznivců účinkujících, přátel z mnoha farností, věřících i nevěřících. Podobně jako třeba v Rajhradě udržuje i komunita na Olomoucku čilé kontakty i po skončení této jednorázové akce. Pořádají společné výlety, promítání filmů, plánují vánoční oratorium, pomáhají si při propagaci a organizaci dalších akcí jednotlivých církví. ${ }^{39}$

\section{Pašije v Kroměříži}

I kroměřížské pašije se soustředí kolem jediného člověka, jenž svou tvořivostí, invencí, hudebními schopnostmi a velkým charismatem dokáže nadchnout skupinu přátel i neznámých lidí k velkému komunitnímu dílu. Alžběta Dolečková (roz. Němčáková) začala psát písně oslavující události pašijového týdne už ve třinácti letech. Pašijový muzikál pod názvem Až na smrt. O umučeni a poslednich okamžicích Krista uvedla se společenstvím Taženi ke Kristu (veřejně prezentováno pod zkratkou TAKK ${ }^{40}$ ) 6. dubna 2014, tedy v době, kdy jí bylo 16 let. ${ }^{41}$ Inscenaci se daří každoročně obnovovat, jarní pašije roku 2017 jsou tedy třetí v pořadí. Zcela zásadním východiskem kroměřížského pašijového muzikálu je v tomto případě komunitní sdílení víry a tradice modliteb chvály. Společenství TAKK se schází každý páteční večer, tráví společně několik hodin a značnou část zabírá právě zpěv a zdokonalování se v hudebním a pěveckém výrazu ve speciálním typu modlitby prostřednictvím písní. Ve společenství se potkává zhruba 25 lidí ve věku

37 Sdružení H4O - Hope for Olomouc vzniklo v roce 2014 a podporuje spolupráci evangelických církví především v oblasti charitativních a kulturních projektů. Patří k nim Apoštolská církev, Bratrská jednota baptistů, Církev bratrská, Církev Nová naděje, Slovo života Olomouc, Československá církev evangelická, Baptisté Olomouc a Křestanské sbory.

38 Kapacita Moravského divadla Olomouc je 398 sedadel. Inscenace měla v 16 hodin veřejnou generálku, v 19 hodin pak premiéru, jež byla zároveň jediným představením inscenace. Akce měla masivní propagaci i na sociálních sítích, byla natočena doprovodná videa dostupná na kanálu YouTube, internetová stránka přinášela průběžně aktualizované informace o procesu zkoušek.

39 „Po Pašijich se lidi ještě více sblížili, neřeší se odchylky v teologických výkladech Bible“, dodává k tomu Beková a upřesňuje svoji pozici jednotícího elementu divadelně-hudebních aktivit vưči různým věkovým, církevním i uměleckým skupinám různorodého společenství: „Já se cítím všude zdejší.“ Osobní rozhovor s Jarmilou Bekovou, 26. 8. 2016. Záznam uložen v archivu autorky.

40 Název odkazuje k jednomu verši z Písně písni. Dostupné online na http://www.takk.estranky.cz/.

41 Osobní rozhovor s Alžbětou Dolečkovou. V Kroměříži, 18. 10. 2016. Záznam uložen v archivu autorky. Datum premiéry citováno podle programu k inscenaci. Až na smrt. Program pašijového muzikálu sdružení TAKK. Nedatováno. 
Akce je vhodná i pro Boha neznalé. Sondy do amatérského náboženského divadla na Moravě ...

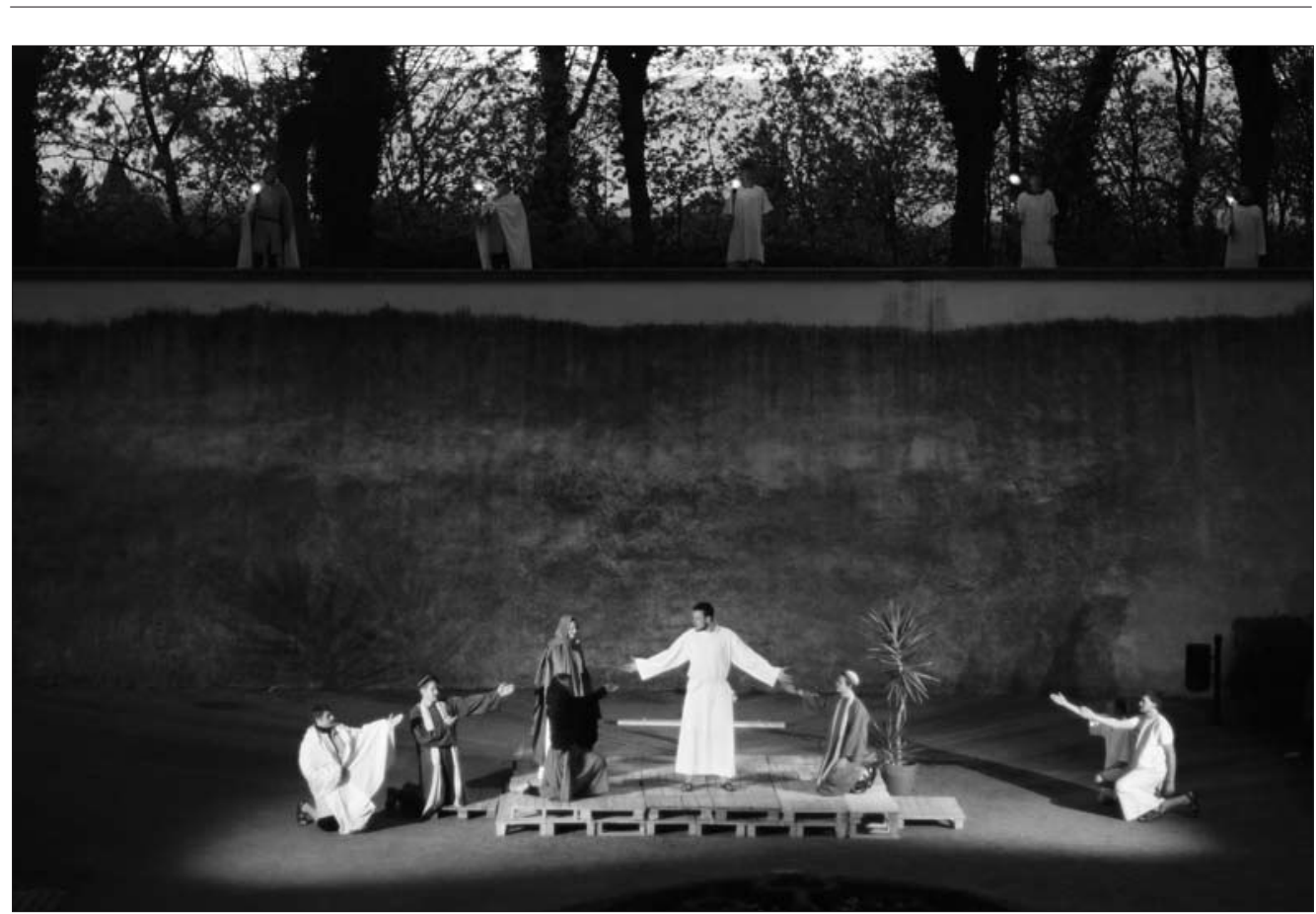

Obr. 7: Až na smrt. O umučení a posledních okamžicích Krista. Společenství Taženi ke Kristu Kroměříz. Provedení 18. 4. 2015 u zdi zámku v Tovačově. Foto Barbora Němčáková.

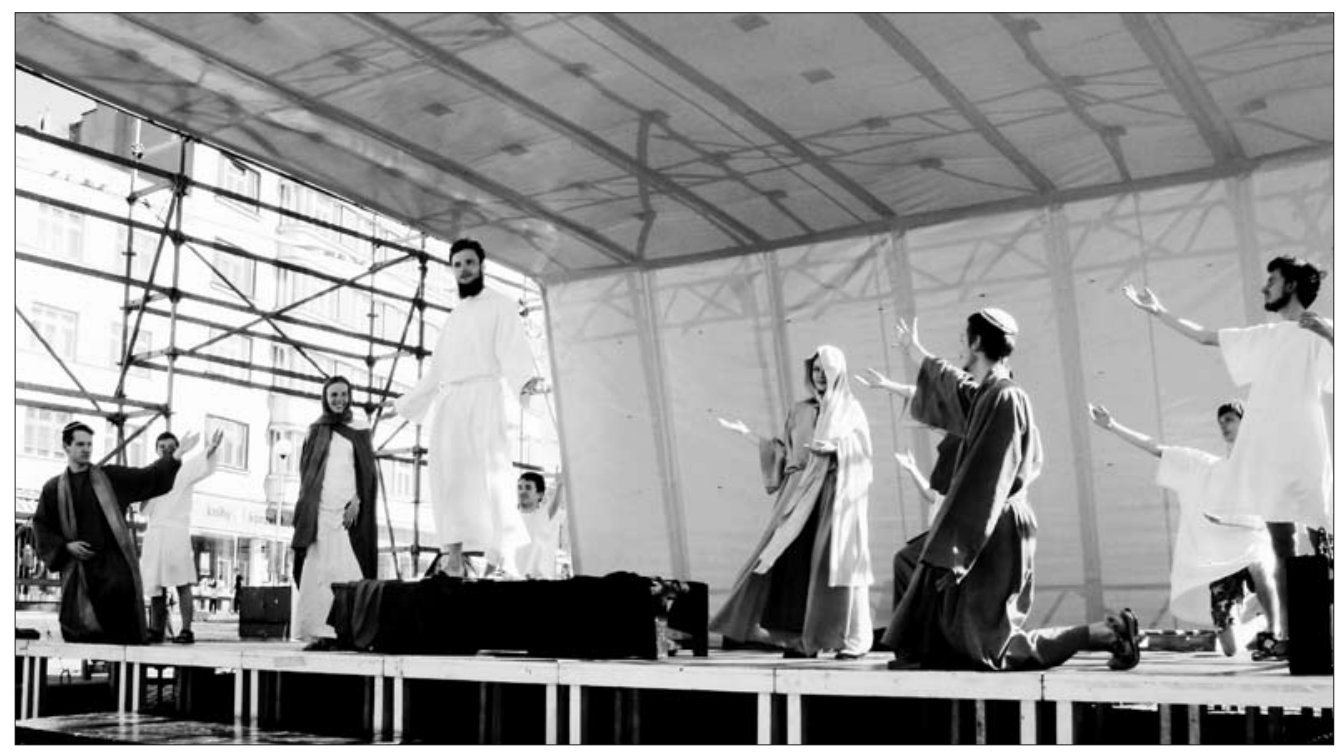

Obr. 8: Až na smrt. O umučení a posledních okamžicích Krista. Společenství Taženi ke Kristu Kroměříž. Provedení 2. 7. 2016 v Kroměříži. V roli Krista Artur Kozik. Foto Barbora Němčáková. 
15-27 let, pro záměr inscenovat pašijový muzikál dokázali získat dalších 30 přátel z blízkého okolí Kroměříže a především otce Artura Kozika z farnosti Bílovice, podle Dolečkové „ideálního představitele Ježíše Krista“. Inscenace je určena pro kostelní prostory a jen výjimečně se hrála jinde. ${ }^{42}$ Bývá uváděna v průběhu postní a velikonoční doby, představení se soustředí do doby po Neděli velikonoční, protože součástí inscenace je i vzkř́šsení, které předtím nelze předvádět. Druhým obdobím roku, v němž se skupina dokáže sejít, jsou zářijové slavnosti Povýšení sv. Kříže. Nástrojově poměrně rozsáhlá kapela ${ }^{43}$ doprovází sólisty a sbor, kteří vytvářejí živé obrazy a vykonávají prostorové aranže ilustrující konkrétní situace z pašijového příběhu (setkání u Piláta, nesení Kříže, dialog s Veronikou, pieta atd.). Hudba doprovází písňové texty, ale zní i v mezihrách, kdy se herci připravují na další scénu. Rovněž text vypravěče, který pašije uvádí a popisuje scénu pod křížem těsně před ukřižováním, je komponován jako hudební part. Jde tedy reálně o zhruba 60 minut autorské hudby. Texty písní se soustředují na reflexi konkrétní situace nebo na sebereflexi postav v situaci. Kostýmy odpovídají standardizované představě, již nastolují pro pašijový prríběh například dětské ilustrované bible. Vojáci a biřici mají kostýmy římských vojáků, tuniku kombinovanou s ochrannými „kovovými prvky“ na prsou, kolenou a předloktí ušité z lesklé šedivé látky, Panna Maria obléká bílý šat až na zem a modrý šátek zahalující vlasy, u většiny účinkujících se v kostýmu objevuje nějaký odkaz na Blízký Východ nebo přímo Palestinu. Většinu kostýmů si kroměřížští farníci půjčují z Hulína, kde hráli jinak koncipované pašije v roce 2000. Další výdaje jednotlivých představení jsou spojeny s profesionálním zvučením, cestovným a př́padným občerstvením na zájezdových představeních. Herci hrají zadarmo, výtěžek z hojně navštívených pašijíi ${ }^{44}$ uchovává společenství jako rezervu pro další reprízy.

Divadelní zkušenost je v kroměřížském společenství přítomna minimálně. Alžběta Dolečková tíhne k muzikálovému způsobu vyjádření, mezi inspiračními zdroji jmenuje tradiční i moderní muzikály. ${ }^{45}$ Režisérem, možná lépe řečeno aranžérem hereckých a pohybových partií, je Jiř́i Kalmus, ochotnický herec kroměřížského souboru Klub Starý pivovar. Jakkoli má kroměřížské společenství menší ambici a výsledný tvar je rozhodně méně pompézní než pašije olomoucké, nemůže si stěžovat na menší zájem diváků.

42 V roce 2015 společenství uvedlo muzikálové pašije na nádvoří zámku v Tovačově a v bazilice na sv. Kopečku (18. a 19. 4. 2015). Referuje o tom facebooková událost $A \check{z}$ na smrt. Tovačov a sv. Kopeček. Pozvánka na tato dvě uvedení muzikálových pašijí na stránkách Mládež děkanátu Kroměříž dala název i této studii. Dostupné online na http://www.mladezkromeriz.signaly.cz/2015/muzikalove-pasije-az-na-smrt-18-19-4-vtovacove-a-na-sv-kopecku/.

43 Nástrojové obsazení představují klávesy, kytary, šestero houslí, příčná flétna, djembe a bicí.

44 Podle Dolečkové nelze návštěvnost nikdy vyčíslit přesně, v kostele sv. Mořice je však vidělo údajně zhruba 600 diváků, v každém místě, kde dosud hráli, se jedná o stovky diváků, řádově 300 lidí na jedno představení.

45 Dolečková jmenuje např́ḱlad tituly Za zvuků hudby, My Fair Lady, Fantóm opery, Zorro, Kleopatra, Drákula, Johanka $z$ Arcu. Kromě prvních tř́i tradičních muzikálů zpracovaných i filmovou produkcí jde u všech ostatních titulů o komerční počiny pražských muzikálových divadel vzniklých po roce 1990. Mezi dalšími inspiračními zdroji jmenovala Dolečková zkušenost s vánočním divadlem Víti Marčíka. Divadelník Víta Marčík má ve svém repertoáru jak velikonoční př́iběh s názvem Moravské pašije (premiéra 13. 2. 2009), tak nativní příběh Setkání před Betlémem, který se hraje od roku 2000 ve dvou základních variantách a v různorodém obsazení. Zdroj internetové stránky Víti Marčíka. Dostupné online na http://www.vitamarcik.cz. 
V domovské Kroměříži inscenace $A z ̌$ na smrt opakovaně zaplnily diváky kostel sv. Mořice, „vyprodaly“ kostely ve Vyškově, baziliku na Sv. Kopečku, velký úspěch měl muzikál na nádvoř́i zámku v Tovačově. Návštěvnost kolísá mezi 3 až 7 stovkami diváků.

Zásadní je opět komunitní rozměr celého počínání. Podle Alžběty Dolečkové stojí na počátku snaha oživit tradiční katolický způsob chválení Boha o zcela nové přístupy, jež přicházejí do Čech, na Moravu a na Slovensko ze západních zemí, především z USA a Austrálie. Tradice „worshipu“ se primárně nesoustředí na kvalitu hudební produkce, ale na prožitek modlitby. Většinou se jedná o jednoduchý nápěv a snadno zapamatovatelná slova chválící Boha, jež se opakují mnohokrát za sebou. Tento způsob hudební a pěvecké modlitby se často rozšiřuje o taneční projevy, extaticky zvednuté ruce a pohupování přítomných, případně další pohybové nebo umělecké aktivity. ${ }^{46}$ Společenství Taženi ke Kristu spolu s několika dalšími moravskými mladými křestanskými skupinami představují alternativu tradičních př́stupů v katolické církvi. ${ }^{47}$ Před každou zkouškou i představením probíhá rituál setkání, během něhož se společenství modlí nejen za dostatek sil pro sebe, ale i za diváky a jejich přijetí příběhu ukřižování a vzkř̌išení Krista.

Dva příklady hudebních zpracování pašijového příběhu jsou ukázkou toho, jak si současná křestanská společenství představují způsob uměleckého sdílení tradičního biblického námětu. Je příznačné, že v žádném ze zmíněných případů nenazývají tvưrci své konání „divadlem“. Ve snaze vystihnout žánr daného projektu co nejpřesněji, se uchylují k terminologii hudební nebo hudebně-divadelní. Nazývat své konání „divadlem“ považují bud' za př́liš bulvární, nebo naopak př́liš vznešené označení svého snažení. Přitom však neomylně používají výsostně divadelní atributy, často se snahou o zapojení intermediálních prvků, výrazné mizanscény nebo tradiční pojmenování složek inscenace. Zároveň v žádné ze sledovaných produkcí nefiguruje pojem režisér, vyjmenováni bývají jen jednotliví účinkující, případně produkční, osvětlovač a zvukař. Zcela se však naplňuje snaha, již vtiskli svým Pašijim profesionální brněnští divadelníci již v roce 1965. Dramaturg Bořivoj Srba tehdy hovořil o divadelním úsilí v době prohlubujícího se procesu společenské diferenciace a neustálého relativizování hodnot, jejichž vlivem se společnost rozpadá na řadu izolovaných lidských jednotek. „Proti této atomizaci chtěli bychom nahrávat silám dostředivým - tomu, co podporuje soudržnost lidského společenství, co vytváří a upevňuje přátelský kontakt mezi lidmi [...], co pomáhá vytvářet ve vědomí lidí pocit vzájemné vazby v onom humanistickém smyslu slova - a tedy i prasta-

46 Na některých worship videích třeba skupinka lidí při zpěvu improvizovaně maluje na velká plátna abstraktní motivy jako výtvarné vyjádření své modlitby a paralelně probíhá v jiné části prostoru taneční performance. $\mathrm{V}$ těchto aspektech a také v hudebním stylu (poprock) jsou patrné rozdíly mezi worshipem a populárními „písněmi z Taizé“. I ty jsou celosvětově proslulé právě opakováním jediného verše a mnohohlasými harmoniemi založenými často na kanonickém principu. Charakter společné modlitby a chvály Pána posiluje mezinárodní komunitu, jež se schází každoročně právě v okolí francouzského města Taizé.

47 „Tento zpo̊sob vyjádření je pro mladé katolíky mnohem autentičtější než skloněné hlavy a odř́kávání mluvených chval“, konstatuje Dolečková. „Mladým lidem více vyhovuje spontánnost modlitby ve spojení s moderní populární hudbou. Jde o to zažehnout Boží lásku prostřednictvím těchto modliteb chval." Osobní rozhovor s Alžbětou Dolečkovou. V Kroměříži, 18. 10. 2016. Záznam uložen v archivu autorky. 
ré mýty, v nichž jsou uloženy základní zkušenosti člověka za období několika tisíciletí.“ (KOPECKÝ 1967: 155) Zvažujeme-li v úvodu zmíněné mimoestetické funkce lidového náboženského divadla, nacházíme je u zkoumaných př́ípadů v identické podobě jako teoretici Bogatyrev nebo Srba před osmdesáti nebo šedesáti lety: v potřebě lidí zažívat v rámci příslušné komunity společně sdílenou radost z tvorby, v touze prodloužit pocit náboženského vytržení prostřednictvím zpívaného a inscenovaného příběhu, ve snaze ujistit se o svých duchovních kořenech ve společenství stejně smýšlejících souputníků.

\section{Závěrem}

Předložená studie na několika vybraných příkladech nabídla ukázku toho, jak mohou být dva základní příběhy křestanského roku, narození a vzkř̌išsení Ježíše Krista, zpracovány různorodými komunitami sdruženými bud' na základě náboženské, místní nebo školní příslušnosti k jedinému místu, úmyslu či myšlence. Region střední a jižní Moravy v tomto ohledu představuje tradiční nábožensky silný region, žádný z uvedených příkladů však nesouvisí př́ímo s nějakou výraznější folklórní tradicí, jež by přežila éru komunistického Československa a dochovala se do doby po roce 1990. Z uvedených příkladů jasně vyplývá, že iniciativa a realizace vánočních i pašijových her leží vesměs na aktivitě jedince, ve všech případech této studie jde o ženy. Oslovená společenství pak nesou vstupní ideu až k realizaci bud' v sakrálních nebo světských prostorách, s více či méně výraznými divadelními atributy. Předmětem zkoumání se staly i mimoestetické funkce sledovaných produkcí. V některých př́ípadech jsou tyto funkce silnější než samotné předvedení příběhu narození nebo ukřižování a vzkřríšení Krista. Svou roli hrála potřeba učit se novým věcem a umělecky růst (Betlém Studia Dům). Společenskou, obřadní a komunitní funkci jsme pozorovali v setkáních u Živého Betlému v Rajhradě. Charakter náboženského svátku mají inscenace pašijí, podobně jako u vánočních her i zde převládá potřeba komunitního sjednocení různorodých církví a rozdílných způsobů vyznání víry. „Abychom dobře mohli rozumět narážkám herců, musíme znát sám kolektiv, v němž se představení odbývá: jeho život, zájmy, události“, zdůrazňuje Bogatyrev nutnou kontextualizaci amatérských produkcí lidových sousedských her (BOGATYREV 1940: 42).

Z hlediska divadelní antropologie a teorie divadelní performance je jistě pozoruhodné, s jakým ostychem se v označení jednotlivých produkcí staví jejich tvůrci k pojmu „divadlo“. Jakkoli jde ve všech případech o inscenace s výraznými divadelními prvky, laické vnímání amatérských sdružení považuje své komunitní betlémy nebo pašije za cokoli jiného než divadlo. Tento pojem bývá považován bud' za degradující ušlechtilý úmysl oslavy narození Ježíše Krista, nebo naopak za příliš ušlechtilý, vznešený a „umělecký“ vzhledem k amatérskému obsazení a provedení například muzikálových pašijí. „Studio Dům jsem vytvořila pro radost z divadelní práce“, pronesla v roce 1992 Eva Tálská (KRÁL 1992: 45), jež stála na začátku všech novodobých moravských divadelních betlémů a pašijí. Ze stejné pohnutky vznikají i ostatní komunitní představení s náboženskou i jinou tematikou, lhostejno, jak své snažení přímí účastníci nazývají. Síla komunity 
se prověřuje každým dalším společným setkáním, mší, zpěvem, pamětnickým večerem, slavením svátků nebo zapálením svíčky. Divadlo v tomto výčtu patří k nejsilnějším okamžikům, jejichž estetickou kvalitu umocňuje duchovní zážitek pospolitosti a blízkosti podobně naladěných jedinců.

\section{Bibliografie}

\section{Archiválie}

Až na smrt. O umučeni a poslednich okamžicich Krista [To the Very Death. The Passion and Last days of Christ]. Plakát k inscenaci, pracovní scénář, pracovní nahrávka na DVD. Osobní archiv Alžběty Dolečkové [Poster to the production; work script; work recording, DVD. Personal archive of Alžběta Dolečková].

Betlém [The Bethlehem]. Inscenace Studia Dům. Program k inscenaci 1992, 1994, 1996. Archiv CED Brno. V osobním archivu autorky [Production of Studio Dům. Programme from 1992, 1994 and 1996. Archive of CED, Brno. Personal archive of the author].

Betlém [The Bethlehem]. [Televizní adaptace divadelní inscenace Betlém Studia Dům; TV adaptation of theatre production by Studio Dům]. Česká televize Brno, 1997.

Kronika spolku Crhovská chasa od roku 2014 dosud [Chronicles of the Crhovská chasa Society]. Archiv spolku Crhovská chasa [Archive of the Crhovská chasa Society].

Osobní rozhovor s Jarmilou Bekovou [Interview with Jarmila Beková], Olomouc, 26. 8. 2016. Záznam uložen v archivu autorky [Recording in the author's archive].

Osobní rozhovor s Alžbětou Dolečkovou [Interview with Alžběta Dolečková]. Kroměříž, 18. 10. 2016. Záznam uložen v archivu autorky [Recording in the author's archive].

Osobní rozhovor s Magdou Mlejnkovou [Interview with Magda Mlejnková]. Rajhrad, 3. 11. 2016. Záznam v archivu autorky studie [Recording in the author's archive].

Pracovní scénář Živý Betlém [The Live Bethlehem; work script], [Rajhrad], nedatováno, nestránkováno. Osobní archiv Magdy Mlejnkové [undat. unpag.; personal archive of Magda Mlejnková].

Pracovní scénář Živý Betlém Rajhrad 2008 [The Live Bethlehem Rajhrad 2008; work script], nestránkováno. Osobní archiv Magdy Mlejnkové [unpag.; personal archive of Magda Mlejnková].

Pašije [The Passion] 2016. [online] [citováno dne 20. 7. 2017]. Dostupné online na http:// pasije2016.cz/projekt/.

TÁLSKÁ, Eva. Betlém [The Bethlehem]. In Výprodej 1991-1997. Katalog k festivalu Studia Dům [The Sell-out 1991-1997; Studio Dům Festival catalogue]. Brno: Centrum experimentálního divadla, 1997: 6-21.

\section{Publikace}

BOGATYREV, Petr. 1940. Lidové divadlo české a slovenské [Czech and Slovak Folk Theatre]. Praha: Borový a Národopisná společnost Českoslovanská, 1940.

ČERNÝ, Aleš. 2015. V Rajhradě se ptali: Vzali byste k sobě Josefa s Marií? [They Were Asking in Rajhrad: Would you have Joseph and Virgin Mary?]. MF Dnes (27. 12. 2015): 4B. 
HOLAS, Ivan. 2012. Tradiční živý betlém v Rahradě na Brněnsku přilákal stovky diváků [Traditional Live Bethlehem Attracted Hundreds of Spectators in Brno Region]. Český rozhlas Brno, 26. 12. 2012. [citováno dne 20. 7. 2017] [online]. Dostupné online na http://www. rozhlas.cz/brno/zpravodajstvi/_zprava/tradicni-zivy-betlem-v-rajhrade-na-brnensku-prilakalstovky-divaku-1154046.

HORÁKOVÁ, Veronika. 2011. Živý Betlém v Rajhradě: ovace sklidil medvídek i sud [The Live Bethlehem in Rajhrad: The Bear and the Barrle were Applauded]. Denik [online] 26. 12. 2011. [citováno dne 20. 7. 2017]. Dostupné online na http://brnensky.denik.cz/zpravy_region/zivybetlem-v-rajhradu-ovace-sklidil-medvidek-i.html.

FEIFALIK, Julius a Jaroslav KOLÁR (edd.). 1986. Lidové hry z Moravy [Folk Plays From Moravia]. Praha: Odeon, 1986.

FOJTÍKOVÁ, Kateřina a Barbara VRBOVÁ a Petr OSLZLÝ (edd.). 2012. Eva Tálská aneb Se mnou smrt a kưn̆ [Eva Tálská or I, the Death and the Horse]. Praha: Pražská scéna, 2012.

HÁNLOVI, Josef a Hana. 2011. Vznik a vydání čtyřarchového Národopisného betlému od Marie Fischerové-Kvěchové [Making and Publishing of the Four-foil Folk Bethlehem by Marie Fischerová-Kvěchová]. Filokartie [online]. [citováno dne 20. 7. 2017] Dostupné online na http:// www.filokartie.cz/vznik-a-vydani-ctyrarchoveho-narodopisneho-betlemu-r-16-c-434.

KOPECKÝ, Jan. 1967. Komedie o umučeni a slavném vzkř̌̌šneni Pána a Spasitele našeho Ježíše Krista [The Comedy of Passion and Glorious Ressurrection of Our Lord and Saviour Jesus Christ]. Praha: Československý spisovatel, 1967.

KRÁL, Karel. 1992. Bílý dům. Neukončený rozhovor s režisérkou Evou Tálskou o prvním roce „Studia Dům“ [The White House. An Unifinished Interview With Director Eva Tálská About the First Year of Studio Dům]. Svět a divadlo (1992): 7: 45.

LANGHAMMEROVÁ, Jiřina. 2004. Lidové kroje z České republiky [Folk Costumes of the Czech Republic]. Praha: Vyšehrad, 2004.

MENČÍK, Ferdinand. 1894. Prostonárodni hry divadelní. 1. díl Vánoční hry [Folk Theatre Plays, vol. I., Christmas Plays]. Holešov, 1894.

SOUČEK, Stanislav. 1929. Rakovnická vánoční hra [Christmas Play From Rakovník]. Brno: Filosofická fakulta s podporou Ministerstva školství a národní osvěty, 1929: [213]-223.

SUŠIL, František (ed.). 1998. Moravské národni pisně [Moravian Folk Songs]. 5. vyd. Praha: Argo/ Mladá fronta, 1998.

ZDENĚK, Hynek. 2015. Živý Betlém v Rajhradě měl rekordní úspěch. Ježíška opět „dodali“ místní [The Live Bethlehem in Rajhrad Had a Record-breaking Success. Baby Jesus Supported by Locals As Usual]. 27. 12. 2015. MF Dnes [online] 26. 12. 2015. [citováno dne 20. 7. 2017] Dostupné online na http://brno.idnes.cz/zivy-betlem-v-rajhrade-06y-/brno-zpravy. aspx?c=A151226_101137_brno-zpravy_kol.

ZÍBRT, Čeněk. 2006. Veselé chvile v životě lidu českého [Happy Moments in the Lives of Czech Folk]. Praha: Vyšehrad, 2006. 


\section{Doc. Mgr. Andrea Hanáčková, Ph.D.}

Katedra divadelních a filmových studií

Filozofická fakulta, Univerzita Palackého Olomouc

andrea.hanackova@upol.cz

Doc. Mgr. Andrea Hanáčková, Ph.D. (1972) vystudovala divadelní vědu na Masarykově univerzitě v Brně, celoživotně se však zabývá především médiem rozhlasu. $V$ praktické tvorbě převažuje zájem o rozhlasový dokument a literárně-dramatické žánry, v teorii se soustředí na strukturalistický a naratologický pohled na rozhlasovou tvorbu. Akademicky působí na filozofické fakultě v Olomouci, tamtéž obhájila dizertační práci „Český rozhlasový dokument a feature v letech 1990-2005. Poetika žánrů" (knižně 2010), na brněnské Janáčkově akademii múzických umění pak práci habilitační s titulem „Performativní modus v autorském rozhlasovém dokumentu" (2017). Aktivně hraje divadlo s vesnickými amatéry a rodinné loutkové divadlo s důrazem na lidové hry českého baroka.

Andrea Hanáčková (1972) graduated from Theatre History and Theory at the Masaryk University, Brno. Her life-long interest lies in broadcasting media; in her praxis, Hanáčková's major fields are radio document and literary dramatic genres, while in her theoretical writing she pays attention mostly to exploring the possibilities of applying Structuralist and naratologic methodology to the research of broadcasting media. She has a position at the Department of Theatre, Film and Media Studies, Palacký University, Olomouc, where she got Ph.D. for her dissertation thesis "Czech Radio Document and Feature 1990-2005: Poetics of Genre" (published in 2010). She received the title of "docent" from the Janáček Academy of Performative Arts in 2017 with a book called "Performative mode in author's radio feature". She takes part in organizing village amateur theatre productions and family puppet theatre, focusing on Czech Baroque folk plays. 